\title{
A simple screening tool for metabolic syndrome risk in the psychiatric patient treated with antipsychotic medication
}

\author{
Martha Carville Patch ,' Margaret Knight, Geoffrey Phillips-McEnany, Emily Chavas, Devan Hawkins \\ School of Nursing, University of Massachusetts Lowell, Lowell Massachusetts, United States
}

Received: May 8, 2014

Accepted: December 11, 2014 Online Published: March 11, 2015

DOI: $10.5430 /$ cns.v3n2p115

URL: http://dx.doi.org/10.5430/cns.v3n2p115

\begin{abstract}
Objective: This study sought to determine whether waist to height ratio (WhtR) can be used to identify psychiatric patients at risk for metabolic syndrome (MetS). Body mass index (BMI) is most often used as the primary determinant for MetS in current screening protocols. There is currently no defined range of values of BMI that determine the level of risk. Psychiatric patients have twice the risk of dying from cardiovascular events than the general population. Cardiovascular disease has been a consequence of metabolic dysregulation that is common to MetS which involves abnormalities in at least three of the following biometric parameters: increase waist circumference, decreased high density lipids (HDL), increased triglycerides (TRG), elevated fasting blood sugar (FBS) and elevated blood pressure (BP). It is well documented that antipsychotic medication is a risk factor for developing MetS.

Methods: A retrospective record review $(n=48)$, evaluated the clinic records of psychiatric patients treated with antipsychotic medication. Data from these records compared the relationship between the WhtR and BMI. The association between WhtR and BMI was analyzed through a Pearson correlation analysis and their respectively sensitivity and specificity for predicting risk for MetS was analyzed using a Receiver Operating Characteristic (ROC) curve. Confounding of the relationships between WhtR and risk of MetS by other risk factors was examined using generalized linear models.

Results: Pearson coefficients of BMI and WhtR revealed a strong positive correlation $r=0.935, p=.01$. Furthermore, WhtR was evaluated utilizing a ROC curve and demonstrated maximum sensitivity between 0.52 and 0.58 with the maximum specificity at $78 \%$. Both WhtR and BMI showed robust measures in determining metabolic syndrome risk. The relationship between WhtR and risk of MetS existed even when controlling for other factors.
\end{abstract}

Conclusions: The ratio of waist circumference to height, can provide a reliable low-cost, non-invasive form of measurement that can be performed in any setting, to monitor the progression of metabolic involvement.

Key Words: Antipsychotic medication, Cardiovascular disease, Metabolic syndrome, Psychiatric patients, Screening tool

\section{Introduction}

It is estimated that individuals who have been diagnosed with a disease involving a formal thought disorder as is seen with schizophrenia, have twice the chance of developing metabolic syndrome (MetS) when compared to the general population. ${ }^{[1]}$ MetS is defined by the American Heart Association (AHA) and the International Diabetes Federation (IDF) as abdominal obesity and two of the following conditions: hypertension, dyslipidemia, and hyperglycemia. ${ }^{[2]}$ Research shows that $31 \%$ to $34 \%$ of the population who live with serious and persistent psychiatric disease compli-

\footnotetext{
*Correspondence: Martha Carville Patch; Email: mpatch2045@ verizon.net; Address: School of Nursing, University of Massachusetts Lowell, Lowell Massachusetts, United States. 
cated by MetS die from cardiovascular disease. The use of antipsychotic medication has been well documented a major risk factor for cardio-metabolic changes that point to MetS. Efforts in recent years to better understand the relationship between these variables has been instrumental in providing data to support the development of evidencebased guidelines for safer clinical practice when the antipsychotic medications are a dimension of the treatment plan. The American Diabetes Association (ADA) and American Psychiatry Association (APA) have developed a guideline schedule for evaluating those biometrics that can identify metabolic syndrome risk. ${ }^{[3]}$ In this guideline, weight gain and subsequently Body Mass Index (BMI) are the predominant parameters evaluated, and waist circumference is recommended only annually.

MetS is not well understood but occurs more frequently than by chance alone in individuals diagnosed with serious mental illness. ${ }^{[4]}$ Known risk factors that contribute to heightened chances for the onset of MetS include central obesity, elevated fasting blood sugar (FBS), elevated blood pressure (BP), elevated triglycerides (TRG), and reduced high density lipids (HDL). Central obesity or abnormally large waist circumference has been debated in the literature as a controversial measurement parameter and has not been consistently considered as a diagnostic criteria for determining MetS. ${ }^{[5]}$

Per the AHA and IDF definition of MetS, waist circumference is the one mandated parameter to determine risk, however this is not always the case in the literature. Saloojee, et al. ${ }^{[6]}$ found that out of 331 persons studied with severe mental illness only $0.6 \%$ had documented waist circumference measured. This study aims to examine the utility of a sensitive non-invasive screening tool which can be used to determine MetS risk in persons receiving antipsychotic medications. This tool utilizes a metric which measures the Waist to Height Ratio (WhtR), calculated by dividing the waist circumference by the height. The WhtR values greater than 0.5 document an increased risk associated with MetS in non-psychiatric populations. ${ }^{[7]}$ WhtR can be used to identify individuals who live with chronic and persistent psychiatric illness, and are at risk for emergence of metabolic syndrome in light of treatment with antipsychotic medications.

The main purpose of this study was to examine WhtR, and BMI with waist circumference, in a community-based sample of individuals diagnosed with chronic and persistent mental illness to determine if this metric is a reliable predictor of metabolic risk. The second purpose of the study was to evaluate whether the WhtR is a more sensitive predictor then either BMI or waist circumference alone in determining the level of metabolic risk. This study sample consisted of $n=48$ of individuals receiving care in a community mental health clinic, who are currently receiving at least one antipsychotic medication.
If the WhtR can be supported as a reliable, economical, noninvasive screening tool for accurately assessing metabolic risk, it can be used to initiate early intervention in those determined to be at risk for MetS. In some cases, the plan may include referral to the primary care provider for the monitoring of the development of comorbidities associated with MetS. In other scenarios, changes or adjustments in antipsychotic medication prescriptions could help to reduce metabolic risk. Conversely, BMI which has long been used as the measurement for metabolic risk in the literature, does not have specific BMI parameters identified that determine metabolic risk.

\subsection{Literature review}

The seriously mentally ill have been found to be more at risk than the general population for developing diabetes and subsequently MetS. ${ }^{[8]}$ Prescribing antipsychotic medication to a person already at risk for developing diabetes can compound this risk and potentiate cardiovascular complications or even death. Currently there are multiple parameters that determine metabolic syndrome depending on the definition used. Weight gain, however, is the most often addressed in the literature to determine whether a patient is at risk for developing diabetes and MetS. However, within the most recent literature, there are references to other parameters that can be used to assess an individual's potential risk, therefore establishing alternative ways to determine metabolic complications. For example, Meyer, et al. references the International Diabetes Federation criteria from 2005 to state that "an emphasis on abdominal adiposity is a necessary condition that must be met for metabolic syndrome to be diagnosed". This parameter, abdominal girth or waist circumference, in addition to a minimum of two to four other criteria such as elevated TRG $>150 \mathrm{mg} / \mathrm{dl}$, low levels of $\mathrm{HDL}<40 \mathrm{mg} / \mathrm{dl}$ in men and $<50 \mathrm{mg} / \mathrm{dl}$ in women, elevated $\mathrm{BP}>130 / 85 \mathrm{mmHg}$ or on hypertensive medication, and elevated FBS $>100 \mathrm{mg} / \mathrm{dl}$ or on insulin or oral hypoglycemic medications, can confirm the presence of MetS.

Carey, et al. ${ }^{[9]}$ also support the International Diabetes Federation's 2005 criteria for MetS when they concluded in their earlier study that after direct measurements "body fat distribution appears more important than obesity in determining insulin resistance and possibly risk of Non-Insulin Dependent Diabetes Mellitus (NIDDM)". More recently the measurement of waist circumference has come under scrutiny by Ashwell, Gunn \& Gibson as an incomplete determinant of potential cardio-metabolic development. Their meta-analysis shows that the ratio of waist circumference to height is a better parameter for determining risk. Since this ratio is a novel measurement tool, a literature search was done on metabolic risk in the mentally ill who are prescribed antipsychotic medication to determine the most utilized form of measurement for potential MetS. 


\subsection{Literature sources}

A search for relevant literature articles was conducted on the following electronic databases: Cumulative Index of Allied Health Literature (CINAHL), Medline, PsychArticles, PsychInfo and Cochrane Database of Systemic Reviews. The search articles were dated from January 1, 2005 through December 31, 2012. They were full text articles and included an abstract. Each database was searched for the keyword terms antipsychotic medication and antipsychotic agents since relevance to the project was dependent on the use of antipsychotic medication. An additional advance Boolean term joining weight gain, metabolic or metabolic syndrome and antipsychotic medication or antipsychotic agent also was used to include keywords in articles that identify the accepted pre-diabetic symptom of weight gain and the prodromal symptom of potential metabolic syndrome. One article, which was found in an additional electronic search, referencing a clinical measurement of waist to height to determine cardiovascular metabolic syndrome, using the terms obesity and adulthood was also included in the relevant article list. This article, Ashwell, Gunn and Gibson, will be sited as the basis for determining the policy improvement in identifying early metabolic syndrome potential in patients receiving antipsychotic medication by measuring the WhtR.

The number of references found through an electronic database search totaled 199. Eighteen duplicates identified in Refworks ${ }^{\circledR}$ were excluded leaving a total of 181 references. Additional references excluded were those in languages other than English and non-journal references such as: editorials, books, and dissertations. Dementia references were excluded unless specific identification of treatment with anti-psychotic medications and reference to metabolic parameters was documented. One hundred and fifteen were excluded due to irrelevant content related to this literary review. Irrelevant causes for exclusion included: animal trials, children, articles on genetic markers, medication trials for efficacy which did not specifically address side effects, and bipolar diagnosis with mood stabilization medications. A total of 66 articles were then reviewed for inclusion and exclusion criteria.

Of the 66 remaining articles, each was reviewed by the author for relevant content. Using the inclusion criteria, 16 articles and an additional two articles hand searched were added for a total of 18 total articles reviewed. Each chosen article needed to include; adult participants with or without adolescent participants, the use of second generation antipsychotic medication, participants diagnosed with a psychotic disorder and a list of specific parameters which were measured to determine metabolic impact. The types of articles included were: random controlled trials (RTC), cross-sectional studies, systematic reviews, meta-analyses, one survey study, one observational study and one interventional study.

Published by Sciedu Press
Articles excluded were those that focused on: adolescents only, the etiology of weight gain or metabolic changes including genetic references, specific treatment management strategies, cost effectiveness, qualitative studies, those on multiple other psychotropic medications and participants that had significant co-morbid medical diagnoses.

\subsection{Literature results}

The first item to be reviewed is to determine the consistency with which the literature measures the effect of antipsychotic medication on the patients studied. BMI was considered the primary measurement to determine potential metabolic impact with 14 out of 18 studies using BMI as a method of measurement. In addition to BMI, ten studies looked at weight gain as an independent parameter of change with or without BMI. Only four references identified waist circumference as a parameter while six studies measured lipid levels, either TRG, HDLs, LDL or cholesterol (CHOL). Two references looked at family history as a parameter of measurement with specific focus on parent's BMI. Fasting glucose was used in four cases and insulin levels were measured in only two instances; one by direct insulin measurement through an insulin suppression test. This was the first insulin suppression test done on patients who were actually taking antipsychotic medication and had a psychotic disorder. In the past testing was performed only on general population volunteers taking antipsychotic medication. ${ }^{[10]}$

Other areas were reviewed as having epidemiologic causes for potential metabolic syndrome, such as gender, age and pre-treatment elevated BMI. Gender was addressed in two studies. Allison, et al. ${ }^{[11]}$ found that there was no significant correlation between baseline BMI and subsequent weight gain when testing ziprasidone, olanzapine, risperidone and haloperidol, by either gender or premorbid BMI. Their hypothesis was based on an artifact created when serial weights are obtained causing a regression toward the mean (RTM) when these weights are not compared to an adequate control group. Allison's results were contradictory from Gebhardt, et al. ${ }^{[12]}$ who showed by regression analysis that a predictive value of higher premorbid BMI determines higher post-treatment BMI. Likewise to be true, gender (female) and lower age also were predictive of greater weight gain. Gebhardt outcomes, however, these were based on a small dataset of 65 participants, with the power being too small to validate its generalization. In only one study, Meyer, et al. did the researchers describe a movement toward metabolic syndrome that did not include weight gain. Meyer's determination of metabolic syndrome was based on HDL, BP, and waist circumference, all of which can be determined without fasting test results. Stahl, et al. ${ }^{[13]}$ advocates for complete pre-morbid condition screening due to the fact that some SGAs can rapidly increase TRG levels resulting in an increase in insulin resistant without an increase 
in weight.

In line with Stahl's recommendation that extensive pretreatment screening tests be performed before antipsychotic treatment begins at least two references discussed the previous treatment obtained by the participants used for these studies. In the systematic review done by AlvarezJimenez, et al. ${ }^{[14]}$ they discuss 51 RCT's examining the use of olanzapine, risperidone and haloperidol and the resulting weight gain and changes in BMI. They argue that the mixed samples of naive treated patients and those with chronic mental illness with a varied history of treatment histories can confound the results of weight gain. He theorizes that when the samples include chronically mentally ill patients that they have in most cases already gained weight with previous med trials and that their weight gain has in some cases plateaued. Therefore mixing them with newly diagnosed patients with psychotic disorders, could artificially lower their weight gain threshold. He believes this factor could be decreased by three or four times the expected weight gain of the newly diagnosed. Kraemer, Minarzyk, et al. ${ }^{[15]}$ after studying 718 participants with newly diagnosed schizophrenia found that these patients had significantly lower rate of metabolic syndrome parameters than patients previously treated with both first generation and second generation antipsychotics. Lipovich, Jacobson, et al. ${ }^{[16]}$ found that after evaluating the degree of early weight gain was determined they could predict the potential of future weight gain looking at olanzapine. Significant weight gain was considered to be an increase of $7 \%$ or more.

The following results of the literature search indicate that weight gain and its associated BMI increases and not central adiposity are used by the psychiatric and pharmaceutical industry as a primary measurement for potential diabetes and metabolic syndrome. In spite of the evidence that weight gain is not always present in metabolic syndrome; and that some individuals do not gain weight while receiving antipsychotics, consistent waist circumference measurements are not globally accepted as a measure for metabolic syndrome screening. Examples of parameters used to measure metabolic syndrome are seen in Table 1.

\section{Methods}

A retrospective record review was performed utilizing data provided from a sample derived from a community mental health clinic. The researcher used this convenient sample to extract data related to metabolic risk associated with the prescription of antipsychotic drugs.

The electronic medical record system, of 1,000 clients, was queried to identify those clients treated for a psychotic disorder. Inclusion criteria determined the selection of records which contained a diagnosis of schizophrenia (295.0, 295.10, 295.30, 295.90), schizoaffective disorder (295.70), delusional disorder (297.1) and psychotic disor- der (298.90), ${ }^{[24]} n=214$. Exclusion criteria included all cases with a secondary diagnosis of development or intellectual disability, those with a diagnosis of dementia or records that had missing biometric or lab data, leaving, $n=89$. Of the 89 remaining records, 48 records $(22 \%)$ met all the biometric measures available for review criteria to determine metabolic risk: BP, height, weight, waist circumference, TRG, HDL and either FBS or Hemoglobin A1c (HbA1c). In these 48 records all biometric and lab values were obtained within a 15 day period and therefore their respective records were included in the study. A 15-day time span was chosen to assure that lab values and biometric data were obtained without possible significant change to ether value over an expanded time frame.

Lab values were either obtained from the clinic laboratory services, or from the primary care provider's medical records. Data extracted from these records did not include cultural or ethnic details due to lack of consistent information downloaded on the electronic medical records in 2012. Since many of the clinic records were originally created years prior to installation into the electronic medical record, cultural and ethnic detail was not obtained when the patients started treatment in the clinic.

\subsection{Measures}

For the purpose of this study metabolic syndrome was defined by the combined criteria from the AHA and the IDF. Common measures between the AHA and IDF criteria included the presence of an enlarged waist circumference (abdominal adiposity), as a necessary factor for metabolic syndrome. Both the AHA and IDF specify that in females the waist must be greater than 35 inches, and in males greater than 40 inches. Two other laboratory findings must also be present to identify metabolic syndrome, they are either: TRG over $150 \mathrm{mg} / \mathrm{dl}$, HDL less than $40 \mathrm{mg} / \mathrm{dl}$ in males and $50 \mathrm{mg} / \mathrm{dl}$ in females, FBS greater than $110 \mathrm{mg} / \mathrm{dl}$, and blood pressure greater than $135 \mathrm{mmHg}$ systolic or $85 \mathrm{mmHg}$ diastolic. HbA1c with a cut-off of 6.2 (for normal range) was used for those cases without a fasting blood sugar. ${ }^{[25]}$

\subsection{Data collection}

Biometric data was extracted from the electronic medical record and placed in an Excel spreadsheet. The data collected included: blood pressure, height, weight and waist circumference from the individual client visit notes. WhtR was calculated by dividing waist circumference in inches by height in inches. BMI was calculated using the documented weight in pounds and height in inches in the following equation, $($ ht $\times 703) /(w t \times w t)$. Medication(s) for hypertension, hyperlipidemia or hyperglycemia was recorded as a positive value for their respective conditions on the Excel sheet. Laboratory data were also collected and collated with blood pressure, height, weight and waist circumference if dated within a 15-day span. 
Table 1: Metabolic syndrome measurement parameters

\begin{tabular}{|c|c|c|c|c|c|c|c|}
\hline Citation & Study design & Analysis & Sample & Variables Studied & Measurement & Implications & Findings \\
\hline $\begin{array}{l}\text { Meyer JM, et } \\
\text { al. }{ }^{[4]}\end{array}$ & Meta analysis & $\begin{array}{l}\text { The change in proportion of } \\
\text { subjects with Metabolic } \\
\text { Syndrome (MetS) and } \\
\text { individual criteria was } \\
\text { compared between } \\
\text { antipsychotic treatment } \\
\text { groups. }\end{array}$ & 661 & $\begin{array}{l}\text { First generation } \\
\text { antipsychotic (FGA) and } \\
\text { second generation } \\
\text { anti-psychotics (SGA) }\end{array}$ & WC, BP, HDL & $\begin{array}{l}\text { Need to replicate } \\
\text { findings in an unbiased } \\
\text { study }\end{array}$ & $\begin{array}{l}\text { Stratification of antipsychotic from } \\
\text { the least metabolic effect to the } \\
\text { most. BMI or wt. not needed for } \\
\text { diagnosis of MetS Hypothesis that } \\
4 \text { parameters needed for a } \\
\text { diagnosis of MetS was disproved }\end{array}$ \\
\hline $\begin{array}{l}\text { Citromere L, } \\
\text { et al. }{ }^{[5]}\end{array}$ & $\begin{array}{l}\text { Literature } \\
\text { review and } \\
\text { meta-analysis }\end{array}$ & $\begin{array}{l}\text { MetS with olanzapine use, the } \\
\text { general population and the } \\
\text { seriously mentally ill. }\end{array}$ & 135 & $\begin{array}{l}\text { olanzapine other SGAs, } 1^{\text {st }} \\
\text { generation antipsychotics. }\end{array}$ & $\begin{array}{l}\text { Wt., BMI, } \\
\text { glucose, } \\
\text { insulin or lipids }\end{array}$ & $\begin{array}{l}\text { Mental ill pts. are at risk } \\
\text { of MetS with or without } \\
\text { olanzapine use }\end{array}$ & $\begin{array}{l}\text { Wt. gain and positive MetS } \\
\text { parameters are seen: } 1 \text { ) mentally } \\
\text { ill; 2) general population; 3) } \\
\text { olanzapine patients }\end{array}$ \\
\hline $\begin{array}{l}\text { Holt I, et } \\
\text { al. }^{[8]}\end{array}$ & $\begin{array}{l}\text { Systematic } \\
\text { review }\end{array}$ & $\begin{array}{l}\text { Addressed the role of genetics, } \\
\text { environment, and } \\
\text { antipsychotic medication in } \\
\text { obesity seen in the mentally } \\
\text { ill. }\end{array}$ & 105 references & $\begin{array}{l}\text { Areas searched: 1) serious } \\
\text { mental illness. 2) genetic } \\
\text { predisposition. 3) } \\
\text { pathogenesis of wt. gain. 4) } \\
\text { antipsychotic medication } \\
\text { used }\end{array}$ & $\begin{array}{l}\text { BMI, waist } \\
\text { circumference }\end{array}$ & $\begin{array}{l}\text { Other factors influence } \\
\text { obesity in this pt } \\
\text { population, in addition } \\
\text { to antipsychotics }\end{array}$ & $\begin{array}{l}\text { Obesity is more likely to be seen in } \\
\text { the seriously mentally ill. Cause of } \\
\text { obesity in the chronically mentally } \\
\text { ill is due to genetics and } \\
\text { environment. }\end{array}$ \\
\hline $\operatorname{Kim}_{a l^{[10]}} \mathrm{SH}$, et & $\begin{array}{l}\text { Interventional } \\
\text { study }\end{array}$ & $\begin{array}{l}\text { Measure the relationship } \\
\text { between BMI and insulin } \\
\text { resistance }\end{array}$ & 54 & $\begin{array}{l}\text { Olanzapine risperidone } \\
\text { aripiprazole }\end{array}$ & $\begin{array}{l}\text { BMI, insulin } \\
\text { suppression } \\
\text { test }\end{array}$ & $\begin{array}{l}\text { This was the first } \\
\text { insulin resistant testing } \\
\text { with psychiatric } \\
\text { patients receiving } \\
\text { antipsychotic treatment }\end{array}$ & $\begin{array}{l}\text { Olanzapine treated pts are more } \\
\text { Insulin resistant than those on } \\
\text { Risperidone or aripiprazole Pts on } \\
\text { SGA similar BMI and Insulin } \\
\text { resistant as general Population }\end{array}$ \\
\hline $\begin{array}{l}\text { Allison DB, } \\
\text { et al. }{ }^{[1]}\end{array}$ & Meta analysis & $\begin{array}{l}\text { Whether drug-induced wt. } \\
\text { gain was moderated by } \\
\text { baseline BMI }\end{array}$ & 470 & $\begin{array}{l}\text { ziprasidone, olanzapine, } \\
\text { risperidone and } \\
\text { haloperidol }\end{array}$ & BMI & $\begin{array}{l}\text { Baseline BMI has no } \\
\text { effect on the amount of } \\
\text { wt. gain after } \\
\text { antipsychotic treatment. }\end{array}$ & $\begin{array}{l}\text { No significant findings that there is } \\
\text { a correlation between baseline } \\
\text { BMI and subsequent wt. gain }\end{array}$ \\
\hline $\begin{array}{l}\text { Ephardt S, et } \\
\text { al. }^{[12]}\end{array}$ & $\begin{array}{l}\text { Retrospective } \\
\text { cross-sectional } \\
\text { design. }\end{array}$ & $\begin{array}{l}\text { The study was to determine } \\
\text { whether other factors, such as } \\
\text { family BMI, history } \\
\text { premorbid BMI, age and } \\
\text { gender effect wt. gain from } \\
\text { antipsychotic medications. }\end{array}$ & $\begin{array}{l}94 \text { reduced to } 65 \\
\text { participants }\end{array}$ & $\begin{array}{l}\text { 1) On either: clozapine, } \\
\text { olanzapine or risperidone. } \\
\text { 2) treatment for psychotic } \\
\text { disorder. 3) no medical or } \\
\text { neurological disorders }\end{array}$ & $\begin{array}{l}\text { Premorbid } \\
\text { BMI, BMI of } \\
\text { parents, }\end{array}$ & $\begin{array}{l}\text { After the inclusion and } \\
\text { exclusion criteria were } \\
\text { applied to the study } \\
\text { group the sample size } \\
\text { was reduced to } 65 \\
\text { participants. Power } \\
\text { number of participants } \\
\text { is questionable for } \\
\text { predictive qualities }\end{array}$ & $\begin{array}{l}\text { 1) increase BMI of parents } \\
\text { predicted increase BMI patients. 2) } \\
\text { regression analysis shows a } \\
\text { predictive value of higher } \\
\text { pre-morbid BMI to determine } \\
\text { higher BMI with antipsychotic } \\
\text { use. 3) lower age and sex (female) } \\
\text { are also predictive of greater wt. } \\
\text { gain. }\end{array}$ \\
\hline $\begin{array}{l}\text { Stahl S M, et } \\
\text { al. }^{[13]}\end{array}$ & $\begin{array}{l}\text { Clinical } \\
\text { overview }\end{array}$ & $\begin{array}{l}\text { Overview of cardio-metabolic } \\
\text { risk induced by antipsychotic } \\
\text { drugs }\end{array}$ & $\begin{array}{l}48 \text { articles } \\
\text { referenced }\end{array}$ & $\begin{array}{l}\text { clozapine, olanzapine, } \\
\text { risperidone, quetiapine, } \\
\text { ziprasidone, aripiprazole }\end{array}$ & $\begin{array}{l}\text { BMI, wt. gain, } \\
\text { FBS, TRG, } \\
\text { HDL, waist } \\
\text { circumference }\end{array}$ & $\begin{array}{l}\text { Addresses Diabetic } \\
\text { ketoacidosis side effect } \\
\text { of SGA. Questions } \\
\text { whether there is an } \\
\text { acute receptor-mediated } \\
\text { action of SGAs on } \\
\text { insulin resistance } \\
\text { without gaining weight. }\end{array}$ & $\begin{array}{l}\text { Guidelines for pre-morbid } \\
\text { condition screening. Some SGAs } \\
\text { rapidly inc TRG and resulting } \\
\text { insulin resistance w/o inc in } \\
\text { weight. }\end{array}$ \\
\hline $\begin{array}{l}\text { Alvarez-Jime } \\
\text { nez } \mathrm{M} \text {, et } \\
\text { al. }^{[14]}\end{array}$ & $\begin{array}{l}\text { Systematic } \\
\text { Review }\end{array}$ & $\begin{array}{l}\text { Critical review of RCTs }{ }^{*} \\
\text { involving wt. gain with FGA } \\
\text { and SGA }\end{array}$ & 51 studies & $\begin{array}{l}\text { olanzapine, risperidone } \\
\text { and haloperidol }\end{array}$ & BMI, wt. gain & $\begin{array}{l}\text { Using mixed samples of } \\
\text { patients can alter } \\
\text { estimates of wt gain by } \\
3 \text { to } 4 \text { times. Chronic } \\
\text { patients might have } \\
\text { stabilized wt. gain prior } \\
\text { to testing. }\end{array}$ & $\begin{array}{l}\text { Comparing mixed samples of } \\
\text { first-episode and chronic patients } \\
\text { as well as diverse diagnostic } \\
\text { groups in RCTs does not } \\
\text { accurately estimate wt. gain } \\
\text { results. }\end{array}$ \\
\hline $\begin{array}{l}\text { Kraemer } \mathrm{S} \text {, } \\
\text { et al. } .^{[15]}\end{array}$ & $\begin{array}{l}\text { Observational } \\
\text { study }\end{array}$ & $\begin{array}{l}\text { To assess the prevalence of } \\
\text { metabolic syndrome in } \\
\text { patients with schizophrenia } \\
\text { after } 3 \text { months of treatment. }\end{array}$ & 718 & $\begin{array}{l}\text { olanzapine, risperidone } \\
\text { quetiapine, other SGA, } \\
\text { typical antipsychotics }\end{array}$ & $\begin{array}{l}\text { TRG, HDL, } \\
\text { BP, FBS, BMI }\end{array}$ & $\begin{array}{l}\text { Longer period of } \\
\text { observation be } \\
\text { recommended. }\end{array}$ & $\begin{array}{l}\text { New patients to medication had } \\
\text { significant lower values of } \\
\text { metabolic syndrome parameters }\end{array}$ \\
\hline $\begin{array}{l}\text { Lipkovich I, } \\
\text { et al. }{ }^{[16]}\end{array}$ & $\begin{array}{l}\text { Post-Hoc } \\
\text { analysis of } \\
\text { clinical trial } \\
\text { data }\end{array}$ & $\begin{array}{l}\text { Evaluating the predictive } \\
\text { value of future weigh gain } \\
\text { based on early wt. gain or } \\
\text { increase BMI. }\end{array}$ & $\begin{array}{l}\text { 52-week study with } \\
669 \text { participants, } \\
\text { 28-week study with } \\
102 \text { participants }\end{array}$ & olanzapine & BMI, Wt. gain & $\begin{array}{l}\text { Early wt. gain can } \\
\text { predict potential future } \\
\text { wt. and BMI changes. }\end{array}$ & $\begin{array}{l}84 \% \text { of patients who gained less } \\
\text { than } 0.64 \mathrm{Kg} / \mathrm{m}^{3} \text { in } \mathrm{BMI} \text { by week } 3 \\
\text { will gain less than } 3 \mathrm{Kg} / \mathrm{m}^{3} \text { in } \\
26-34 \text { weeks }\end{array}$ \\
\hline $\begin{array}{l}\text { Ascher-Svan } \\
\text { um H, et } \\
\text { al. }{ }^{[17]}\end{array}$ & RCT & $\begin{array}{l}\text { Determine whether gender or } \\
\text { agent used affects acute wt. } \\
\text { gain. Broaden therapeutic } \\
\text { effect: +/- signs of psychosis, } \\
\text { depression or mental/physical } \\
\text { functioning }\end{array}$ & $\begin{array}{l}700 \text { women, } 1296 \\
\text { men }\end{array}$ & olanzapine and haloperidal & $\begin{array}{l}\text { Wt gain, BMI, } \\
\text { BPRS }{ }^{* *} \text {, } \\
\text { MADRS } \text { and } \\
\text { SF-36 Physical } \\
\text { and mental } \\
\text { components }\end{array}$ & $\begin{array}{l}\text { These results cannot be } \\
\text { generalized due the } \\
\text { specific agents used. } \\
\text { Improvement in clinical } \\
\text { outcomes with SGA use } \\
\text { cannot be correlated to } \\
\text { wt gain. }\end{array}$ & $\begin{array}{l}\text { Regression analysis proved gender } \\
\text { not a significant variable Improved } \\
\text { clinical indicators correlated with } \\
\text { more wt. gain, olanzapine group } \\
\text { had better scores than haloperidol } \\
\text { group }\end{array}$ \\
\hline $\begin{array}{l}\text { Buckley PF, } \\
\text { et al. }{ }^{18]}\end{array}$ & $\begin{array}{l}\text { A } 10 \text { question } \\
\text { survey }\end{array}$ & $\begin{array}{l}\text { To determine the disparity } \\
\text { between guideline knowledge } \\
\text { and clinical practice. 1) use of } \\
\text { SGA. 2) clinical concerns over } \\
\text { risks. 3) monitoring for wt } \\
\text { gain and metabolic change }\end{array}$ & 258 & $\begin{array}{l}\text { All Second Generation } \\
\text { Antipsychotics (SGA) }\end{array}$ & $\begin{array}{l}\text { BMI, Family } \\
\text { or personal } \\
\text { history BP, } \\
\text { FBS, lipids, } \\
\text { waist } \\
\text { circumferenc. }\end{array}$ & $\begin{array}{l}\text { 2/3 of treaters with } \\
\text { SGAs are not following } \\
\text { guidelines for } \\
\text { determining MetS. } \\
\text { Further education re: } \\
\text { guidelines for } \\
\text { monitoring needed. }\end{array}$ & $\begin{array}{l}\text { Approximately } 1 / 3 \text { of responders } \\
\text { consistently monitored glucose } \\
\text { and lipid, and } 4 \%-6 \% \text { performed } \\
\text { waist circumference }\end{array}$ \\
\hline $\begin{array}{l}\text { Roerig JL, et } \\
\text { al. }^{[19]}\end{array}$ & $\begin{array}{l}\text { Systematic } \\
\text { Review }\end{array}$ & $\begin{array}{l}\text { Reviews etiology of wt. gain } \\
\text { phenomena }\end{array}$ & $\begin{array}{l}30 \text { tabled articles, } \\
228 \text { references }\end{array}$ & All 10 SGA, haloperidol & Wt. gain, BMI & $\begin{array}{l}\text { Genetic data is needed } \\
\text { to determine why } \\
\text { different persons have } \\
\text { different responses to } \\
\text { same meds }\end{array}$ & $\begin{array}{l}\text { Variability of wt.gain across SGAs } \\
\text { coupled with variability of wt.gain } \\
\text { in pts receiving same SGA } \\
\text { questions multifactorial } \\
\text { phenomena }\end{array}$ \\
\hline $\begin{array}{l}\text { Parsons B, et } \\
\text { al. }^{[20]}\end{array}$ & $\begin{array}{l}\text { Systematic } \\
\text { review }\end{array}$ & $\begin{array}{l}\text { Estimates of mean wt. change } \\
\text { and } \% \text { of persons experiencing } \\
\text { wt. gain or loss across studies. }\end{array}$ & $\begin{array}{l}1742 \text { short-term wt. } \\
\text { effects participants, } \\
1649 \text { long-term wt. } \\
\text { effects participants }\end{array}$ & $\begin{array}{l}\text { amisulpride, olanzapine, } \\
\text { risperidone, ziprasidone, } \\
\text { haloperidol and placebo }\end{array}$ & Wt. gain & $\begin{array}{l}\text { Providers prescribing } \\
\text { practices can be } \\
\text { influenced by potential } \\
\text { weigh gain with some } \\
\text { SGAs. }\end{array}$ & $\begin{array}{l}\text { Ziprasidone wt. gain in both short } \\
\text { and long term studies was similar } \\
\text { to placebo. }\end{array}$ \\
\hline $\begin{array}{l}\text { Faulkner G, } \\
\text { et al. }\end{array}$ & $\begin{array}{l}\text { Selective } \\
\text { review of } \\
\text { interventionsa } \\
\text { nd RCTs for } \\
\text { schizophrenic } \\
\text { pts. }\end{array}$ & $\begin{array}{l}\text { An overview of } \\
\text { pharmacologic and } \\
\text { non-pharmacologic } \\
\text { interventions for wt. gain and } \\
\text { metabolic changes }\end{array}$ & 56 & $\begin{array}{l}\text { olanzepine. risperidone, } \\
\text { clozapine, ziprasidone, } \\
\text { antidepressants mood } \\
\text { stabilizers }\end{array}$ & Wt. gain & $\begin{array}{l}\text { Lifestyles changes can } \\
\text { influence wt. gain from } \\
\text { antipsychotics }\end{array}$ & $\begin{array}{l}\text { Prevention of wt. gain and the } \\
\text { promotion of wt. loss are possible } \\
\text { for individuals treated with } \\
\text { antipsychotics. }\end{array}$ \\
\hline Gentile S. ${ }^{[22]}$ & $\begin{array}{l}\text { Systematic } \\
\text { review }\end{array}$ & $\begin{array}{l}\text { Analyze the potential patient } \\
\text { and drug related factors that } \\
\text { lead to wt. gain from SGAs in } \\
\text { long term treatment. }\end{array}$ & $\begin{array}{l}242 \text { articles, } 6 \\
\text { articles hand } \\
\text { searched }\end{array}$ & $\begin{array}{l}\text { 1) SGAs study's reviewed: } \\
\text { clozapine aripiprazole } \\
\text { olanzapine quetiapine } \\
\text { risperidone. 2) Length of } \\
\text { treatment. 3) med doses }\end{array}$ & Wt. gain & & $\begin{array}{l}\text { Risperidone was found to be more } \\
\text { influential on both patient and drug } \\
\text { related factors that increase wt. } \\
\text { gain. }\end{array}$ \\
\hline $\begin{array}{l}\text { Perez } \\
\text { Iglesias R, et } \\
\text { al. }^{[23]}\end{array}$ & $\begin{array}{l}\text { Prospective } \\
\text { RCT }\end{array}$ & $\begin{array}{l}\text { Qualify the wt. gain induced } \\
\text { by FGA and SGA in cohort of } \\
\text { drug-naïve subjects after } 1 \\
\text { year of treatment. }\end{array}$ & 144 & $\begin{array}{l}\text { haloperidol, risperidone, } \\
\text { olanzapine }\end{array}$ & Wt. gain, BMI & $\begin{array}{l}\text { Wt gain is continuous } \\
\text { through-out first year. } \\
\text { FGA and SGA use wt. } \\
\text { gain were not } \\
\text { significantly different. }\end{array}$ & $\begin{array}{l}\text { Pts continued to gain weight } \\
\text { during the full year of treatment. } \\
\text { Differences in wt. gain patterns } \\
\text { were seen over 1year, but not } \\
\text { difference in amount of wt. gained. }\end{array}$ \\
\hline $\begin{array}{l}\text { Verma S, et } \\
a l .^{[24]}\end{array}$ & $\begin{array}{l}\text { Cross-sectiona } \\
\text { 1 study. }\end{array}$ & $\begin{array}{l}\text { On logistic regression lower } \\
\text { BMI, female gender and } \\
\text { younger age were associated } \\
\text { with clinically significant wt. } \\
\text { gain }\end{array}$ & $\begin{array}{l}56 \text { patients } \\
\text { admitted }\end{array}$ & $\begin{array}{l}\text { First generation } \\
\text { antipsychotic and Second } \\
\text { generation antipsychotic. }\end{array}$ & $\begin{array}{l}\text { BMI, TRG, } \\
\text { LDL, CHOL }\end{array}$ & & $\begin{array}{l}\text { Significant increases in BMI, } \\
\text { TRG, LDL and total CHOL from } \\
\text { baseline readings to } 6 \text { months } \\
\text { readings. }\end{array}$ \\
\hline
\end{tabular}




\subsection{Ethical considerations}

The University of Massachusetts Lowell Institutional Review Board approved this study. Data collection, by the student investigator, occurred between June 6, 2013 until November 27, 2013, $(n=48)$. During the data extraction period an amended IRB approval was obtained in order to obtain additional demographic information. The following data was added to the extraction sheet: age, gender and number of years of treatment. Anonymity was maintained by using a combination of patient initials (first character of first name, first and last character of the last name) and the date the biometric data was obtained. All data were secured in a locked drawer in a locked office.

Table 2: Psychiatric client's records characteristic table (N $=48)$

\begin{tabular}{|c|c|c|}
\hline & Range & Mean(SD) \\
\hline Age & $22-73$ & $46.19(12.11)$ \\
\hline WhtR & $0.43-0.81$ & $0.63(0.10)$ \\
\hline \multirow[t]{2}{*}{ BMI } & $19.84-47.00$ & $31.75(7.03)$ \\
\hline & $\mathbf{N}$ & $\%$ \\
\hline \multicolumn{3}{|l|}{ Gender } \\
\hline Male & 39 & 81 \\
\hline Female & 9 & 19 \\
\hline \multicolumn{3}{|l|}{ Antipsychotics } \\
\hline FGA $^{*}$ & 6 & 13 \\
\hline $\mathrm{SGA}^{* *}$ & 28 & 58 \\
\hline SGA(2) & 11 & 23 \\
\hline FSA+SGA treatment in years & 3 & 6 \\
\hline$>10 \mathrm{yrs}$ & 38 & 79 \\
\hline$<10$ yrs & 10 & 21 \\
\hline Hypertension & 25 & 52 \\
\hline Dyslipidemia & 36 & 75 \\
\hline Hyperglycemia & 16 & 33 \\
\hline \multicolumn{3}{|l|}{ Disease risks $^{* * *}$} \\
\hline 0 & 9 & 19 \\
\hline 1 & 12 & 25 \\
\hline 2 & 18 & 37 \\
\hline 3 & 9 & 19 \\
\hline
\end{tabular}

* First generation antipsychotic; ${ }^{* *}$ Second generation antipsychotic

${ }^{* * *}$ Risk of hypertension, dyslipidemia or hyperglycemia

\subsection{Data analysis}

All data was downloaded to IBM's SPSS Statistics software (version 19). The participants' demographic information was analyzed using descriptive statistics that included frequencies for categorical values and mean values and ranges for WhtR and BMI. Pearson's correlation and the ROC curve were used to determine both the WhtR and the BMI levels of sensitivity and specificity.
ROC curves In order to explore how well WhtR, BMI, and waist circumference predict being at risk for metabolic syndrome, ROC curves were created using SPSS version 19. The curves were generated using WhtR, BMI, and waist circumference as test variables and either being at risk or not at risk of having metabolic syndrome as the state variable.

Generalized linear models Using SPSS version 19, generalized linear models with Poisson regression was used to explore whether the relationship between WhtR and having metabolic syndrome was confounded by either age, sex, years on medication, or the number of drugs being taken. Univariate models testing each of the potential confounders' relationship to metabolic syndrome were run, along with a multivariable model including all of the confounders.

\subsubsection{Participants}

The records of 48 individuals were included in this study: 39 males and 9 females. The mean age of the data was 46.19 with a Standard Deviation of 12.11 years. Treatment for greater than 10 years was found in $79 \%$ of the population. And $46 \%$ of the population demonstrated metabolic syndrome with abdominal obesity and two other positive parameters (see Table 2).

\subsubsection{Prevalence of MetS in the population}

Using the WhtR parameter of over 0.50 , as a parameter that demonstrates a confirmation of abdomen obesity. Forty percent show evidence of metabolic syndrome over 0.50 with two risk factors (elevated BP, elevated TRG or hyperglycemia elevated over $110 \mathrm{mg} / \mathrm{dl}$ or an HbA1c greater than $6.2 \%$ ). Abdominal obesity with one risk factor is seen in $30 \%$, and abdominal obesity with no risk factors is seen in $10 \%$ of the total population. Of all the cases $80 \%$ have values of WhtR greater than 0.50 (see Figure 1,2).

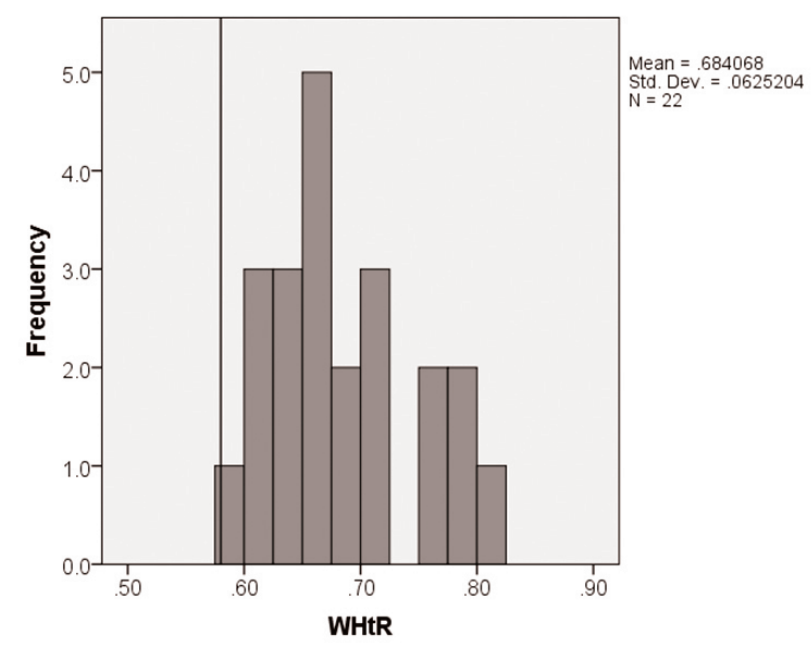

Figure 1: Frequency of waist to height ratio in subjects with metabolic syndrome 


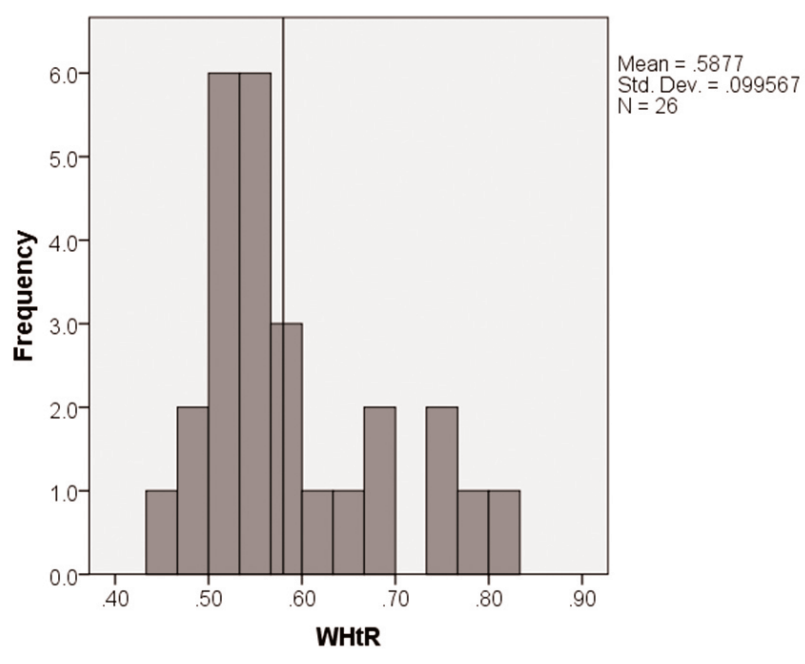

Figure 2: Frequency of waist to height ratio without metabolic syndrome

\subsubsection{Correlations between WhtR and BMI}

A correlation was made between BMI and WhtR. The Pearson correlation coefficient between BMI and WhtR in the entire sample shows $r$ value was 0.935 with a significance of $p=.01$, shown in Table 3 .

Table 3: Pearson's correlation between BMI and WhtR

\begin{tabular}{lll}
\hline & WhtR & BMI \\
\hline WhtR & 1 & $.935^{* *}$ \\
BMI & $.935^{* *}$ & 1 \\
\hline
\end{tabular}

${ }^{* *}$ Correlation is significant at the 0.01 level (2-tailed)

\subsubsection{ROC curves comparison}

Generalized linear mixed models: Using SPSS version 19. Generalized linear models were used to explore whether the relationship between WhtR and having metabolic syndrome was confounded by either age, sex, years on medication, or the number of drugs being taken. Univariate models testing the relationship each of the potential confounders' relationship to metabolic syndrome were run, along with a multivariate model including all of the confounders.

\subsubsection{ROC curves}

As is shown in Table 4, WhtR, BMI, and waist circumference are all robust tests for assessing this population's risk of metabolic syndrome with areas under the curve greater than 0.50 (the null-hypothesis indicating no significant ability to assess risk). All of the values are significant at less than 0.01 .

\subsubsection{Generalized linear mixed models}

As is shown in Table 5, in a univariate analysis of the association between WhtR, age, sex, years on anti-psychotic drugs, the number of anti-psychotic medications being taken and risk of metabolic syndrome, only WhtR showed a clear significant association $(p=.013)$, with each 0.1 increase in WhtR resulting in a $79.2 \%$ (95\% Confidence Interval [CI]: $13.3 \%$ to $183.3 \%$ ) increased probability of being at risk for metabolic syndrome. The number of anti-psychotic medications being taken is not significant at $p=.05$, but does show some association, with those taking only one anti-psychotic drug having a $55.5 \%$ (95\% CI: $80.7 \%$ lower probability to $3.2 \%$ higher probability) lower probability of being at risk for metabolic syndrome than those who take two antipsychotic drugs $(p=.059)$.

As is shown in Table 5, when controlling for age, sex, years on medication, and the number of medications being taken, only WhtR has a significant association with being at risk for metabolic syndrome $(p=.029)$, with each 0.1 increase in WhtR resulting in a $75.6 \%$ (95\% CI: $6.0 \%$ to $190.7 \%$ ) increased probability of being at risk for metabolic syndrome. All other potential confounders, including the number of antipsychotic medications being taken, which was close to significant in the univariable model, show non-significant relationships in this multivariable model.

\section{Discussion}

\subsection{ROC curves}

Based on the different areas under the curve shown in Table 4, WhtR, BMI, and waist circumference are all good models for predicting individuals in this population being at risk for metabolic syndrome. Being above the 0.50 cut-off line indicates that the as sensitivity (the ability to accurately diagnosis someone with the metabolic syndrome) increases significant specificity (the ability to not inaccurately diagnose some with metabolic syndrome) is not lost and as specificity increases, significant sensitivity is not lost. The confidence intervals for all of the test variables making it difficult to determine if one test variable is better than any of the others, most likely due to the relatively small sample size.

\subsection{Generalized linear models analysis}

As indicated by both the univariate analysis in Table 5 and the multivariate analysis in Table 6 , WhtR has a strong relationship with risk of metabolic syndrome, which exists even when controlling for several potential confounders. This indicates that it is less likely to be due to any association between these confounders and the risk of metabolic syndrome that is causing this association, but rather due to the relationship between WhtR itself and metabolic syndrome itself.

The answer to the question of whether WhtR is a sensitive screening tool to measure metabolic risk, can also be supported when reviewing the correlation between BMI and WhtR. BMI has long been used in the literature for determining metabolic risk. ${ }^{[26]}$ A correlation to WhtR of greater than $93 \%$ would support the finding that WhtR is a valid 
form of measure in determining metabolic risk as it compares to BMI.

BMI values although used to measure metabolic risk have never been specifically identified when a metabolic syndrome risk occurs. BMI above 25 identifies an individual in the overweight category however, this does not confirm the individual is at metabolic syndrome risk. Some recent studies may support the fact that a BMI greater than 25 but less than 35 can offer protection from cardiovascular disease as the "obesity paradox". [27]

Table 4: Comparison of ROC analysis using WhtR, BMI and waist circumference to predict risk of metabolic syndrome

\begin{tabular}{llllcc}
\hline \multirow{2}{*}{ Variable } & \multirow{2}{*}{ Area Under the Curve } & \multirow{2}{*}{ Std. Error } & \multirow{2}{*}{ Asymptotic Sig } & \multicolumn{2}{c}{ 95\% Confidence Interval } \\
\cline { 5 - 6 } & & 0.068 & $<.001$ & Lower & Upper \\
\hline Waist-to-Height Ratio & 0.796 & 0.072 & .001 & 0.662 & 0.931 \\
BMI & 0.768 & 0.073 & .001 & 0.627 & 0.628 \\
Waist Circumference & 0.770 & 0.910 \\
\hline
\end{tabular}

Table 5: Univariable analysis of association between risk of metabolic syndrome, WhtR and potential confounders

\begin{tabular}{|c|c|c|c|c|}
\hline \multirow{2}{*}{ Variable } & \multirow{2}{*}{ Rate ratio } & \multirow{2}{*}{ P-Value } & \multicolumn{2}{|c|}{ 95\% Confidence Interval } \\
\hline & & & Lower & Upper \\
\hline Waist-to-Height Ratio & 1.792 & 0.013 & 1.133 & 2.833 \\
\hline Age (Years) & 1.014 & 0.446 & 0.978 & 1.051 \\
\hline \multicolumn{5}{|l|}{ Sex } \\
\hline Female & 1.625 & 0.310 & 0.636 & 4.153 \\
\hline Male & $1^{*}$ & & $1^{*}$ & $1^{*}$ \\
\hline \multicolumn{5}{|c|}{ Years on Anti-Psychotic Medications } \\
\hline Less Than 10 & 0.433 & 0.259 & 0.101 & 1.854 \\
\hline 10 or Greater & $1^{*}$ & & 0.331 & 0.795 \\
\hline \multicolumn{5}{|c|}{ Number of Anti-Psychotic Medications } \\
\hline 1 & 0.446 & 0.059 & 0.193 & 1.032 \\
\hline 2 & $1^{*}$ & & $1^{*}$ & $1^{*}$ \\
\hline
\end{tabular}

*Reference group

Recent findings have revealed epidemiological evidence showing that overweight and low-obesity categories may have a protective cardiovascular effect in the presence of chronic conditions (e.g., heart disease or diabetes) or older age when compared with normal weight or severe obesity. A current meta-analysis of 97 studies has included more than 2.88 million subjects and over 270,000 deaths with the aim of studying the relationship between BMI and all-cause mortality. Obesity grade 1 was not related with the endpoint of death or cardiovascular complications, suggesting that the excess of deaths in obese patients was mainly due to increased mortality at higher BMI levels. ${ }^{[27]}$

Table 6: Multivariable analysis of association between risk of metabolic syndrome, WhtR and potential confounders

\begin{tabular}{|c|c|c|c|c|}
\hline \multirow{2}{*}{ Variable } & \multirow{2}{*}{ Rate ratio } & \multirow{2}{*}{ P-Value } & \multicolumn{2}{|c|}{ 95\% Confidence Interval } \\
\hline & & & Lower & Upper \\
\hline Waist-to-Height Ratio & 1.756 & 0.029 & 1.060 & 2.907 \\
\hline Age (Years) & 0.999 & 0.984 & 0.943 & 1.060 \\
\hline \multicolumn{5}{|l|}{ Sex } \\
\hline Male & $1^{*}$ & 0.530 & $1^{*}$ & $1^{*}$ \\
\hline Female & 1.368 & & 0.514 & 3.614 \\
\hline \multicolumn{5}{|c|}{ Years on Anti-Psychotic Medications } \\
\hline Less Than 10 & 0.705 & 0.738 & 0.090 & 5.496 \\
\hline 10 or Greater & $1^{*}$ & & $1^{*}$ & $1^{*}$ \\
\hline \multicolumn{5}{|c|}{ Number of Anti-Psychotic Medications } \\
\hline 1 & 0.481 & 0.481 & 0.201 & 1.151 \\
\hline
\end{tabular}

*Reference group 
More often increasing BMI values are identified as potential metabolic syndrome risks. This vague determinant for metabolic risk is difficult to correlate with specific values identified with the WhtR although the correlation coefficient clearly identifies a strong relationship with increasing values of both the WhtR and BMI.

\section{Conclusions}

\subsection{Limitations}

The size of the sample records used for this study was only $22 \%$ of all the clients with a psychotic disorder in the clinic, thus yielding an insufficient sample set for significant findings except the correlation between WhtR and BMI. This lack of consistent screening found in the population of people receiving antipsychotic medication is well documented in the literature. ${ }^{[28]}$

Some of the confounding influences on the results is gender of the participant records. There are $n=9$ females with $n$ $=39$ males. However in the ${ }^{[17]}$ study with olanzapine and haloperidol, they found no difference in weight gain between sexes. The use of second generation antipsychotics was $58 \%$ of the total population, which is expected those clients with psychotic mental illness are usually prescribed second-generation antipsychotics as the preferred choice to decrease the incidence of tardive dyskinesia, which can be since the result of first generation antipsychotic use.

Also an additional confounding influence could be ques- tioned due to the age and length of treatment of the clients studied. This can be can be seen in the demographics which demonstrate an older, more chronically treated population with a possibility of years with multiple drug trials. Age alone, with a mean of 46 years could definitely have an effect on the metabolic risk increasing with age. Due to the ages of the studied population and length of treatment, further research is needed to evaluate the WhtR tool for metabolic risk in a younger, more treatment naive group.

\subsection{Implications for practice}

The WhtR a simple, low-cost, non-invasive screening tool for the psychiatric client receiving antipsychotic medication, may identify those in need of further metabolic screening. Options such as medication changes, referrals for specialized treatment and lifestyle changes may be initiated based on changing WhtR values rather than screening based on time in treatment. ${ }^{[7]}$

\section{Acknowledgements}

A special acknowledgement to Bridgewell Counseling Services for supporting this study, especially Robert Stearns, Andrew Stephens, LICSW and Renee Heusser, LICSW who made it possible. Angela Nannini, PhD for her invaluable editing support.

\section{Conflicts of Interest Disclosure}

The authors declare no competing interest.

\section{References}

[1] Riordon HJ, Antonini P, Murphy MF. Atypical antipsychotics and metabolic syndrome in patients with schizophrenia: Risk factors, monitoring and healthcare implications. American Health and Drug Benefits. 2011; 4(5): 292-302.

[2] Alberti KG, Eckel RH, Grundy SM, et al. Harmonizing the metabolic syndrome: A joint interim statement of the International Diabetes Federation task force on epidemiology and prevention; National Heart, Lung, and Blood Institute; American Heart Association; World Heart Federation; International Atherosclerosis Society; and International Association for the Study of Obesity. Circulation. 2009; 120(16): 1640-1645. PMid:19805654. http://dx.doi.org /10.1161/CIRCULATIONAHA. 109.192644

[3] Cohn T, Sernyak M. Metabolic monitoring for patients treated with antipsychotic medication. Canadian Journal of Psychiatry. 2006; 51(8): 492-501. PMid:16933586.

[4] Meyer JM, Davis VG, Goff DC, et al. Change in metabolic syndrome parameters with antipsychotic treatment In the CATIE schizophrenia trial: Prospective data from phase 1. Schizophrenia Research. 2007; 10: 273-286. http://dx.doi.org/10.1016/j .schres.2007.12.487

[5] Citrome L, Holt R IG, Walker DJ, et al. Weight gain and changes in metabolic variables following olanzapine treatment in schizophrenia and bipolar disorder. Clinical Drug Investigation. 2011; 31(7): 455-
482. PMid:21495734. http://dx.doi.org/10.2165/1158906 0-000000000-00000

[6] Saloojee S, Burns J, Motala A. Very low rates of screening for metabolic syndrome among patients with severe mental illness in Durban, South Africa. BioMed Central Psychiatry. 2014; 14: 228. http://dx.doi.org/10.1186/s12888-014-0228-5

[7] Ashwell M, Gunn P, Gibson S. Waist-to-height ration is better screening tool than waist circumference and BMI for adult cardiometabolic risk factors: systematic review and meta-analysis. Obesity Reviews. 2011; 13: 275-286. PMid:22106927. http://dx.doi.o $\mathrm{rg} / 10.1111 / \mathrm{j} .1467-789 \mathrm{X} .2011 .00952 . \mathrm{x}$

[8] Holt RI, Peveler RC. Obesity, serious mental illness and antipsychotic drugs. Diabetes, Obesity \& Metabolism. 2009; 11(7): 665679. PMid:19476478. http://dx.doi.org/10.1111/j.1463-1 326.2009.01038.x

[9] Campbell L, Carey DG, Chisholm DJ, et al. Abdominal fat and insulin resistance in normal and overweight women: direct measurements reveal a strong relationship in subjects at both low and high risk of NIDDM. Diabetes [Internet]. 1996 May [cited 2012, November 21]. 45(5): 633. Available from: http://go.galegroup.com .libproxy.uml, edu

[10] Kim SH, Nikolics L, Abassi F, et al. Relationship between body mass index and insulin resistance in patients treated with second generation antipsychotic agents. Journal of Psychiatric Research. 2009; 44: 493-498. http://doi:10.1016/j.psychires. 2009 .11 .007 
[11] Allison DB, Loebel AD, Lombardo I, et al. Understanding the relationship between baseline BMI and subsequent weight change in antipsychotic trials: Effect modification or regression to the mean. Psychiatry Research. 2009; 170: 172-176. http://dx .doi.org/1 $0.1016 / \mathrm{j} \cdot$ psychres.2008.10.007

[12] Gebhardt S, Haberhausen M, Heinzel-Guttenbrunner M, et al. Antipsychotic-induced body weight gain: Predictors and a systematic categorization of the long-term weight course. Journal of Psychiatric Research. 2008; 43(6): 620-626. http://dx.doi.org/10. 1016/j.psychires. 2008.11.001

[13] Stahl SM, Mignon L, Meyer JM. Which comes first: Atypical antipsychotic treatment or cardiometabolic risk? Acta Psychiatrica Scandinavica. 2008; 119(3): 171-179. http://dx.doi.org/10. $1111 / j .1600-0447.2008 .01334 . x$

[14] Alvarez-Jimenez M, Gonzalez-Blanch C, Crespo-Facorro B, et al. Antipsychotic-induced weight gain in chronic and first-episode psychotic disorders: A systematic critical reappraisal. CNS Drugs. 2008; 22(7): 547-562. PMid:18547125. http://dx.doi.org/1 $0.2165 / 00023210-200822070-00002$

[15] Kraemer S, Minarzyk A, Forst T, et al. Prevalence of metabolic syndrome in patients with schizophrenia, and metabolic changes after 3 months of treatment with antipsychotics results from a German observational study. BMC Psychiatry. 2011; 11: 173. PMid:22044502. http://dx.doi.org/10.1186/1471-244X-11-173

[16] Lipovich I, Jacobson JG, Hardy TA, et al. Early evaluation of patient risk for substantial weight gain during olanzapine treatment for schizophrenia, schizophreniform, or schizoaffective disorder. BMC Psychiatry. 2008; 8: 78. http://dx.doi.org/10.1186/1471-2 44X-8-78

[17] Ascher-Scanum H, Stensland M, Zhongyun Z, et al. Acute weight gain, gender and therapeutic response to antipsychotics in the treatment of patients with schizophrenia. BMC Psychiatry. 2005; 5: 3-3.

[18] Buckley PF, Miller DD, Singer B, et al. Clinician, recognition of the metabolic adverse effects of antipsychotic medications. 2005; 79(23): 281-288. http://dx.doi.org/10.1016/j.schres . 2005.0 4.010

[19] Roerig JL, Steffen KJ, Mitchell JE. Atypical anti-psychotic-induced weight gain: Insights into mechanisms of action. CNS Drugs. 2011;
25(12): 1035-1059. PMid:22133326. http://dx.doi.org/10. 2165/11596300-000000000-00000

[20] Parsons B, Allison DB, Loebel A, et al. Weight effects associated with antipsychotics: A comprehensive database analysis. Schizophrenia Research. 2008; 110: 103-110. http://dx.doi.o rg/10.1016/j.schres.2008.09.025

[21] Faulkner Gary, Cohn T. Pharmacologic and non-pharmacologic strategies for weight gain and metabolic disturbance in patients treated with antipsychotic medications. Canada Journal of Psychiatry. 2006; 51(8): 502-511. PMid:16933587.

[22] Gentile S. Contributing factors to weight gain during long-term treatment with second-generation antipsychotics. A systematic review and clinical implications. Obesity Reviews: An Official Journal of the International Association for the Study of Obesity. 2009; 10(5): 620-626. http://dx.doi.org/10.1111/j.1467-789x. 2009.00589.x

[23] Perez-Igesias R, Cresp-Facorro B, Martinez-Garcia O, et al. Weight gain induced by haloperidol, risperidone and olanzapine after 1 year: Findings of a randomized clinical trial in a drug-naive population. Schizophrenia Research. 2008; 99(1-3): 13-22. http://dx.doi .o rg/10.1016/j.schres.2007.10.022

[24] Verma S, Liew A, Subramaniam M, et al. Effect of treatment on weight gain and metabolic abnormalities in patients with firstepisode psychosis. Australian and New Zealand Journal of Psychiatry. 2009; 43: 812-817. PMid:19670054. http://dx.doi.org/1 $0.1080 / 00048670903107609$

[25] American Psychiatric Association: Diagnostic and Statistical Manual of Mental Disorders. (Fourth Edition Text Revision). Washington, DC: American Psychiatric Association; 2000.

[26] Lab USA, metabolic laboratory normal scale. 2014.

[27] Brunero S, Lamont S. Systemic screening for metabolic syndrome in Consumers with severe mental illness. International Journal of Mental Health Nursing. 2009. http://dx.doi.org/10.1111/j.144 7-0349.2009.00595.x

[28] Cerezo C, Segura J, Praga M, et al. Guidelines Updates in the Treatment of Obesity or Metabolic Syndrome and Hypertension. Current Hypertension Reports. 2013; 15: 196-203. http://dx.doi.org/1 $0.1007 / \mathrm{s} 11906-013-0337-4$ 